\title{
The Correlation of Santri's Personal Hygiene to the Incidences of Scabies in Pesantren Al-Kautsar Simalungun (a boarding school)
}

\author{
Fanissa ${ }^{1}$, Yunilda Andriyani ${ }^{2}$ \\ ${ }^{1}$ Faculty of Medicine, Universitas Sumatera Utara \\ ${ }^{2}$ Department of Parasitology, Faculty of Medicine, Universitas Sumatera Utara
}

\begin{abstract}
Scabies is a skin disease caused by the parasite named Sarcoptes scabiei. Scabies commonly found in developing countries, including Indonesia. There is a high prevalence of scabies in children and adolescents. Scabies is an infectious disease influenced by either the presence or absence of risk factors for scabies in each individual. Scabies often occurs among people who live together. Objectives. This study intends to see whether there is an influence of personal hygiene behavior on the incidence rate of scabies. Method. This study is an observational analytic study with a cross-sectional design. Primary data were used in this study. The data were collected by doing history-taking, physical examination, as well as conducting ink tests on lesions on the patient's body to observes scabies, and interviews/questionnaires to observes personal hygiene behavior. The samples were chosen by a simple random sampling method. The data that has been collected will be analyzed using the fisher's exact statistical test. Results. There are 91 respondents, including 39 men and 52 women with the age range of 12-15 years. Forty eight respondents $(52,7 \%)$ are diagnosed scabies, 74 respondents $(81,3 \%)$ have good personal hygiene, 17 of them $(18,7 \%)$ have a bad personal hygieneConclusion. There is a significant correlation between personal hygiene and the incidence of scabies with $\mathrm{p}$ value of 0,001 .
\end{abstract}

Keyword: Personal Hygiene, Scabies, Action

Abstrak. Skabies merupakan penyakit kulit yang diakibatkan oleh parasit Sarcoptes scabiei. Penyakit skabies banyak ditemukan di negara berkembang, termasuk Indonesia. Prevalensi skabies tinggi pada usia anak-anak dan remaja. Skabies merupakan penyakit menular yang dipengaruhi oleh ada/tidaknya faktor resiko skabies pada tiap individu. Skabies sering terjadi pada sekelompok orang yang hidup bersama. Tujuan. Penelitian ini bertujuan untuk melihat apakah terdapat hubungan antara perilaku kebersihan personal terhadap kejadian penyakit skabies. Metode. Penelitian ini merupakan penelitian observasional analitik dengan desain studi cross-sectional. Data yang digunakan merupakan data primer. Pengambilan data dilakukan dengan melakukan anamnesis, pemeriksaan fisik, serta melakukan tes tinta pada lesi di tubuh pasien untuk hasil skabies, dan wawancara/angket untuk hasil perilaku kebersihan personal. Sampel penelitian diambil dengan metode simple random sampling. Data yang telah dikumpulkan akan dianalisis dengan menggunakan uji statistik fisher's exact. Hasil. Dari 91 responden, 39 laki-laki dan 52 perempuan dengan rentang usia 12-15 tahun, 48 orang $(52,7 \%)$ didiagnosis skabies, 74 orang $(81,3 \%)$ memiliki tindakan yang baik dan 17 orang (18,7\%) lainnya dalam kategori buruk, Kesimpulan. Terdapat hubungan

Corresponding author at:Faculty of Medicine, Universitas Sumatera Utara, Jl. Dr. Mansur No. 5, Kampus USU, Medan, Sumatera Utara, Indonesia, 20155

yunilda@usu.ac.id 
yang signifikan antara tindakan kebersihan personal dengan kejadian penyakit skabies dengan nilai $p=0,001$

Kata Kunci: kebersihan personal, skabies, tindakan

Received 15 January 2020 | Revised 15 January 2020 | Accepted 02 February 2020

\section{Introduction}

Scabies is a disease caused by the parasite Sarcoptes scabiei var. hominis, which could result in discomfort on its sufferers as a clinical manifestation [1]. Scabies generally occurs on individuals who live in groups, for instances those in dorms, boarding schools, correctional institutions, hospitals, densely populated rural areas and nursing homes.

Scabies are more commonly found in developing countries. The incidence rate of scabies varies, from $0.3 \%$ to $46 \%$. These days, scabies has been transmitted to more than 130 million global population. In certain developing countries, the prevalence is high on children and adolescents compared to adults [2].

The incidence of scabies is linked to personal and environmental hygiene. Personal hygene is one of the contributing factors which affects the transmission of scabies. The transmission could take place through either direct or indirect contacts ( through clothes, beds, towels etc.). A densely populated, dirty, and unhygienic area could promote the transmission of scabies [3].

A research at a boarding school in East Jakarta found that the prevalence of students with scabies was $51.6 \%$ [4], while a previous research at another boarding school in Medan reported an incidence rate of 75\% [5]. Another research in Medan discovered that 70\% of the children with scabies had poor personal hygiene [6].

Scabies could be diagnosed from anamnesis, physical examination, as well as some additional tests such as burrow ink test. In this research, the author chose to diagnose scabies through burrow ink test as it was easy and could be performed directly at the research location.

It could be concluded that from the previous researches, the incidence rate of scabies is high on people who live in groups, such as those in boarding schools, and is linked to poor personal hygiene. Thus this research was carried out to assess the correlation between personal hygiene practice and the incidence of scabies at Pesantren Al-Kautsar Simalungun (a boarding school).Research Methods

This cross-sectional study was conducted in Haji Adam Malik General Hospital and University of Sumatera Utara Hospital Medan, Indonesia from September, 2018 until March, 2019. Thirty patients diagnosed with NPC were enrolled by doing anamnesis, physical examination, imaging 
studies, and histopathological examination by Otorhinolaryngologist. The samples had to fulfil the inclusion criteria including no antibiotic therapy in the past 2 weeks and no symptoms of respiratory tract infection. Patients agree to participate in the research and fill the informed consent. This study also had been approved by the Health Research Ethical Committee of Medical Faculty, University of Sumatera Utara, Medan, Indonesia with No: 461/TGL/KEPK FK USURSUP HAM/2018.

\section{Method}

This is an analytic observational research using cross-sectional study design. The population includes all the MTs students at Pesantren Al-Kautsar Simalungun with a total of 264 people. The samples were taken utilizing simple random sampling method [7], as many as 91 people with those who had other dermal diseases other than scabies not taken into samples. This research uses primary data obtained directly from the samples through anamnesis, scabies examination (physical, burrow ink, and microscopic examinations) as well as questionnaire on scabies and personal hygiene practice which has been validated, the scores are divided into two categories with those who answered true $>70 \%$ have good personal hygiene and those who answered true $\leq 70 \%$ are considered to possess bad personal hygiene.

The obtained data are analyzed with univariate and bivariate tests (Fisher's exact test).Microbiological Assay

\section{Results}

\subsection{Respondents' characteristics}

Out of 91 samples, 52 people $(57.1 \%)$ were female and 39 people $(42.9 \%)$ were male with age range of 12-15 years, where 47 people (51.6\%) were 13 years old, 27 people (29.7\%) were 14, 14 people (15.4\%) were 12, and another 3 people (3.3\%) were 15 . The respondents covered 2 levels of education, 61 students $(67.0 \%)$ were at 2 MTs and 30 others (33.0\%) were at 3 MTs.

Table 1 Respondents' characteristics

\begin{tabular}{lcc}
\hline \multicolumn{1}{c}{ Characteristic } & Frequency & Percentage (\%) \\
\hline Gender & 39 & 42.9 \\
Male & 52 & 57.1 \\
Female & & \\
Age & 14 & 15.4 \\
12 & 47 & 51.6 \\
13 & 47 \\
\hline
\end{tabular}




\begin{tabular}{lcc}
\hline 14 & 27 & 29.7 \\
15 & 3 & 3.3 \\
Grade & 61 & \\
2 MTs & 30 & 67.0 \\
3 MTs & & 33.0 \\
Ethnic group & 46 & \\
Batak & 41 & 50.5 \\
Java & 2 & 45.1 \\
Minang & 2 & 2.2 \\
Malay & $\mathbf{9 1}$ & 2.2 \\
\hline Total & & $\mathbf{1 0 0 . 0}$ \\
\hline
\end{tabular}

\subsection{Scabies distribution}

It was found from anamnesis and physical examination that 48 students out of 91 suffered from scabies while the other 43 did not. Among the students with scabies, 12 people posed positive on the ink test and 3 of them had Sarcoptesscabiei found under microscope.

Table 2 Respondents' distribution according to Scabies incidence

\begin{tabular}{ccc}
\hline Scabies (+) & Ink test (+) : 12 & Microscope (+) :3 \\
48 & Ink test $(-): 36$ & Microscope $(-): 45$ \\
\hline Scabies (-) & Ink test $(+):-$ & Microscope $(+):-$ \\
43 & Ink test $(-): 43$ & Microscope (-) :43 \\
\hline
\end{tabular}

\subsection{Distribution of personal hygiene practice}

Table 3 Distribution of responses

\begin{tabular}{|c|c|c|c|c|c|}
\hline \multirow{3}{*}{$\begin{array}{l}\mathbf{N} \\
\mathbf{o}\end{array}$} & \multirow{3}{*}{ Question } & \multicolumn{4}{|c|}{ Answer } \\
\hline & & \multicolumn{2}{|c|}{ True } & \multicolumn{2}{|c|}{ False } \\
\hline & & $\mathbf{F}$ & $\%$ & $\mathrm{~F}$ & $\%$ \\
\hline 1. & $\begin{array}{l}\text { Do you wash your clothes with soap or } \\
\text { detergen? }\end{array}$ & $\begin{array}{l}8 \\
9\end{array}$ & 97.8 & 2 & 2.2 \\
\hline 2. & $\begin{array}{l}\text { Do you put your clothes together with } \\
\text { your friends' clothes in one place? }\end{array}$ & $\begin{array}{l}8 \\
4\end{array}$ & 92.3 & 7 & 7.7 \\
\hline 3. & $\begin{array}{l}\text { Do you wash your hands after } \\
\text { scratching your body? }\end{array}$ & $\begin{array}{l}6 \\
0\end{array}$ & 65.9 & $\begin{array}{l}3 \\
1\end{array}$ & 34.1 \\
\hline
\end{tabular}




\begin{tabular}{|c|c|c|c|c|c|}
\hline 4. & $\begin{array}{l}\text { Do you put your clothes under the } \\
\text { sunlight after wash? }\end{array}$ & $\begin{array}{l}8 \\
9\end{array}$ & 97.8 & 2 & 2.2 \\
\hline 5. & Do you bathe $2 \mathrm{x}$ a day? & $\begin{array}{l}8 \\
0\end{array}$ & 87.9 & $\begin{array}{l}1 \\
1\end{array}$ & 12.1 \\
\hline 6. & $\begin{array}{l}\text { Do you sleep together (in the same bed } \\
\text { with other people)? }\end{array}$ & 1 & 1.1 & $\begin{array}{l}9 \\
0\end{array}$ & 98.9 \\
\hline 7. & $\begin{array}{l}\text { Do you put your bed under the } \\
\text { sunlight once a week? }\end{array}$ & $\begin{array}{l}3 \\
0\end{array}$ & 33.0 & $\begin{array}{l}6 \\
1\end{array}$ & 67.0 \\
\hline 8. & $\begin{array}{l}\text { Do you change your bedsheets once a } \\
\text { week? }\end{array}$ & $\begin{array}{l}4 \\
8\end{array}$ & 52.7 & $\begin{array}{l}4 \\
3\end{array}$ & 47.3 \\
\hline 9. & Do you iron your clothes before use? & $\begin{array}{l}7 \\
2\end{array}$ & 79.1 & $\begin{array}{l}1 \\
9\end{array}$ & 20.9 \\
\hline $\begin{array}{c}10 \\
.\end{array}$ & $\begin{array}{l}\text { Do you put your towel under the } \\
\text { sunlight? }\end{array}$ & $\begin{array}{l}8 \\
9\end{array}$ & 97.0 & 2 & 2.2 \\
\hline
\end{tabular}

From table 3, it could be seen that the majority of the respondents answered false on question number 6,7 dan 8 . As many as 90 students slept together, 61 rarely put their bed under the sunlight, and 43 rarely changed their bedsheets.

Table 4 Distribution of personal hygiene practice

\begin{tabular}{ccc}
\hline $\begin{array}{c}\text { Personal hygiene } \\
\text { practice }\end{array}$ & Frequency & Percentage (\%) \\
\hline Good & 74 & 81.3 \\
Poor & 17 & 18.7 \\
\hline Total & $\mathbf{9 1}$ & $\mathbf{1 0 0 . 0}$ \\
\hline
\end{tabular}

It could be seen that the majority of the respondents, as many as 74 people $(81.3 \%)$ had good personal hygiene practice whereas the other $17(18.7 \%)$ had poor personal hygiene practice.

\subsection{The correlation between personal hygiene practice and the incidence of Scabies}

Table 5 The correlation of personal hygiene practice and scabies incidence

\begin{tabular}{|c|c|c|c|c|c|c|c|c|}
\hline & & \multicolumn{4}{|c|}{ Scabies } & \multirow{2}{*}{\multicolumn{2}{|c|}{ Total }} & \multirow[b]{3}{*}{$\mathrm{p}$-value } \\
\hline & & \multicolumn{2}{|c|}{ Yes } & \multicolumn{2}{|c|}{ No } & & & \\
\hline & & $F$ & $\%$ & $\mathrm{~F}$ & $\%$ & $\mathrm{~F}$ & $\%$ & \\
\hline \multirow{2}{*}{ Personal hygiene practice } & Good & 33 & 36.3 & 41 & 45 & 74 & 81.3 & \multirow{2}{*}{0.001} \\
\hline & Poor & 15 & 16.5 & 2 & 2.2 & 17 & 18.7 & \\
\hline
\end{tabular}




$\begin{array}{lllllll}\text { Total } & 48 & 52.8 & 43 & 47.2 & 91 & 100\end{array}$

There is a significant correlation between the respondents' personal hygiene practice and the incidence of scabies as a p-value of 0.001 was obtained. The respondents diagnosed with scabies who had good personal hygiene were as many as 33 people (36.3\%), while those who had bad personal hygiene accounted for 15 people (16.5\%) Whereas among those who did not suffer from scabies, 41 people $(45.0 \%)$ had good personal hygiene and $2(2.2 \%)$ were included into poor personal hygiene group.

\section{Discussion}

\subsection{Scabies distribution}

There are 4 cardinal signs of scabies as following:

1. Nocturnal pruritus, defined as itchiness at nights as the activity of the mites is higher at hotter temperature and humid condition.

2. This disease occurs on people in groups, for instance the members of a family are usually transmitted together, as well as those in densely populated rural areas as the neighbors who live in vicinity could be transmitted and hypersensitization may happen, in which all members of a family are transmitted with scabies. Although infested with mites, those with no signs and symptoms are known as carriers.

3. There are tunnels (cuniculi) on predilection places in white or grey, as lines with average length of $1 \mathrm{~cm}$, papules and vesicles may be found at the end of the tunnels. If there is a secondary infection, the rash may become polymorphic (pustules, excoriation etc.). The predilection areas are usually places with thin stratum corneum (inbetween fingers, volar surface of the wrist, lateral part of the elbow, anterior part of the armpit, areola mammae (in females), umbilicus, buttock, external genitalia (in males), and lower part of the stomach. In infants, scabies could manifest in palm and foot.

4. Discovering mites are the most definitive diagnosis with one or more life stages of the mites could be found.

Scabies could be diagnosed with Burrow Ink Test (BIT), especially for screening on many patients. The ink test is noninvasive, quick, and easy to perform [9].

This test uses ink to find the fine tunnels on the patients. It is done by putting ink (sheaffer cartridge) in blue or black on papules or suspected lesions. After covering the lesions with ink, 
the ink will be erased with cotton ball soaked with alcohol. If the result is positive, the ink will follow the shape of the fine tunnels of the mites [10].

On every sample, a history taking was carried out with questions of the symptoms associated with scabies, as well as physical examination to see the lesion on the patient's body and additional tests, such as ink test and skin scraping. Out of 91 people, 48 people were found positive with scabies according to the anamnesis and physical examination. As many as 12 people posed positive on the ink test and were all diagnosed with scabies from the anamnesis and physical examination. The ink test is not always positive on scabies patients as it is difficult to find the primary lesion for the ink. In addition, the tunnels are hard to see on people with dark complexion. Out of 12 people with positive ink test, 3 were found to have positive results on skin scraping under the microscope. In skin scraping, there are some things to note as following:

1. Papules recommended for skin scraping are recently formed papules

2. The examination is not to be done on excoriation lesions and those with secondary infection

3. Skin scraping should be superficial and no bleeding should occur

4. Do not scrap only on one lesion, but on some lesions. The mites are frequently found inbetween fingers thus some attention should be paid on those areas

5. Before the skin scraping, put some mineral oil onto the scalpel and the chosen lesions [11].

Although after paying some notice on the previously mentioned things, the mites remains difficult to find on laboratory examination as the mites are in small number. In addition, some scratching may mechanically release some mites and the pus of secondary infection may kill the mites as it is acaricide, thus the hatching eggs only account for $10 \%$ [11]. This causes false negative on scabies patients who have been diagnosed through history taking and physical examination.

There are some risk factors for scabies, and many are found in developing countries. The risk factors include the density of the population and people who have close relationship and direct contact with scabies patients [12]. These become the reasons why students in boarding schools are at risk for suffering from scabies.

\subsection{Distribution of personal hygiene practice}

In this research, only 17 out of 91 students have bad personal hygiene while the other 74 possess good personal hygiene.

Assessing from the number, the majority of the respondents posed good personal hygiene practice. However, there were some questions associated with scabies incidence and the students predominantly answered the questions with responses inferred as poor personal hygiene practice. 
Out of 91 people, as many as 90 people answered yes when they were asked if they slept together / in groups. Theoretically, scabies could be transmitted through two means, as follow:

1. Direct contact (skin with skin contact), for instances hand shake, sleeping together and sexual intercourse

2. Indirect contact (through objects), such as clothes, towels, bed sheets, pillows etc. [8].

3. In addition, 61 out of 91 students stated that they rarely put their bed sheets under the sunlight and 43 seldom changed their bed sheets. The three questions mentioned previously are associated with one another in scabies transmission either through direct or indirect contact.

\subsection{Correlation between personal hygiene practice and scabies incidence}

Out of 17 respondents who had bad personal hygiene, 15 of them were diagnosed with scabies while only 2 were not. After the statistical analysis, p-value of $0.001(<0.05)$ was obtained, inferring that there is an correlation between personal hygiene practice and scabies incidence.

\section{Conclusion}

There is a correlation between personal hygiene practice and scabies incidence.

\section{REFERENCES}

[1] Schmidt, G.D. \& Roberts, L.S. Foundations of Parasitology, 8th edn, $\quad$ McGraw-Hill companies, New York. 2009

[2] WHO. Scabies, Accessed 04 May 2019, Available at: https://www.who.int/lymphatic_filariasis/epidemiology/scabies/en/

[3] Siregar, R.S. Colored Atlas of Quintessence of Skin Diseases, 3rd edn, Penerbit Buku Kedokteran EGC, Jakarta. 2015

[4] Ratnasari, A.F. \& Sungkar, S. Prevalence of Scabies and Related Factors in Pesantren X, East Jakarta ', Journal UI, vol. 2,no. 1. 2014

[5] Asra, H.P. Effects of Student Knowledge and Actions on Personal Hygiene against Scabies Disease (Scabies, The Itch, Gudig, Budukan, Itching Agogo) at the Ar-Raudhatul Hasanah Islamic Boarding School in Medan FK USU, Medan . 2011

[6] Saragih, D.H. Relationship of Child Behavior with Scabies Incidence Rate at Temple Orphanage in Medan Sunggal District 2016, FK USU, Medan. 2016

[7] Notoatmodjo, S. Health Research Methodology. Rineka Cipta, Jakarta. 2012

[8] Handoko, R. P. Skabies, In: Skin and Sex Disease, 7th edn, FK UI, Jakarta. 2017

[9] Leung, V. \& Miller, M., 'Detection of scabies: A systematic review of diagnostic methods', Can J Infect Dis Med Microbiol, vol. 22 , No. 4. 2011

[10] Woodley, D. \& Saurat, J.H. 1981 The Burrow Ink Test and the scabies mite. Journal of the American Academy of Dermatology, vol. 4, No. 6. 1981

[11] Sungkar, S.. 'Penyakit yang disebabkan Artropoda', in : Medical Parasitology Textbook, 4th edn, ed. Sutanto, I., Ismid, I.S., dan Sjarifuddin, P.K., Departemen Parasitologi FK UI, Jakarta, pp.297-300. 2010

[12] Soedarto. Synopsis of Tropical Medicine, Airlangga University Press, Surabaya. 2007 